\title{
Kupffer Cell-derived Cytokines Induce the Synthesis of a Leukocyte Chemotactic Peptide, Interleukin-8, in Human Hepatoma and Primary Hepatocyte Cultures
}

\author{
Amanda J. THORNTON, ${ }^{1}$ JOHN HAM $^{2}$ AND STEVEN L. KUNKEL ${ }^{1}$ \\ ${ }^{I}$ Department of Pathology and ${ }^{2}$ Department of Surgery, University of Michigan Medical School, Ann Arbor, Michigan \\ 48109-0602
}

\begin{abstract}
Communication circuits operating between activated monocytes/macrophages and adjacent hepatocytes in the liver effect important alterations in hepatocyte function. We demonstrate here that primary human hepatocytes and hepatoma cells are able to function as effector cells in the recruitment of inflam. matory cells in hepatic disease and inflammatory states by synthesizing a neutrophil//ymphocyte chemotactic factor, interleukin-8. We have further investigated the possibility that endogenous factors elaborated by activated peripheral blood monocytes and Kupffer cells in the liver are mediators of hepatocytederived interleukin-8 expression. Twenty-four-hour conditioned medium from lipopolysaccharidestimulated peripheral blood monocytes and nonparenchymal human liver cells enriched for Kupffer cells induced a time-dependent increase in interleukin-8 messenger RNA levels in SK-hepatoma cells over a 24-hr period, similar to that seen for tumor necrosis factor- $\alpha$ or interleukin-1 $\beta$ induction of interleukin-8 in primary hepatocytes. Exogenously added lipopolysaccharide or recombinant interleukin-6 had no effect. Cell-associated interleukin-8 antigen was present in SK-hepatoma and primary hepatocytes that had been incubated with macrophage-conditioned medium, tumor necrosis factor or interleukin-1ß. Similarly, neutrophil chemotactic activity was secreted by SKhepatoma cells, a significant proportion of which could be blocked with interleukin-8-specific antiserum. Preincubation of macrophage-conditioned medium with neutralizing antibodies to tumor necrosis factor- $\alpha$ or interleukin-1 $\beta$ reduced its interleukin-8 messenger RNA-inducing capacity. Exposure of SK-hepatoma to conditioned medium followed by removal of the stimulus resulted in a rapid down-regulation of interleukin-8 messenger RNA to $50 \%$ of the maximum level within the first hour. These data suggest that products derived from activated Kupffer cells can modulate hepatoma cells and primary hepatocyte interleukin-8 gene expression. In addition,
\end{abstract}

Received November 9, 1990; accepted July 22, 1991.

This work was supported by National Institutes of Health grants HL31963, HL31237 and DK38149.

Address reprint requests to: Steven L. Kunkel, Ph.D., Department of Pathology, 1301 Catherine Road, Box 0602, Ann Arbor, MI 48109-0602. 31/1/33225 macrophage/monocyte-derived tumor necrosis factor- $\alpha$ and interleukin-1 $\beta$ have major roles in the positive regulatory component of this modulation. (HEPATOLOGY 1992;15:1112-1122.)

The presence of polymorphonuclear cells (PMNs) and/or lymphocytic infiltrates in the liver is associated with several acute and chronic liver disease states, including alcoholic liver disease, chronic and acute hepatitis, biliary tract disease, liver insufficiency associated with sepsis and multiple systems organ failure and acute transplant rejection (1). We recently used three human hepatoma lines (SK-hep, Hep-G2 and Hep 3B), which exhibit varying degrees of functional and biochemical complexity, to demonstrate that human hepatocytes may have the capacity to participate in the recruitment of inflammatory cells into the liver by the production of a PMN/lymphocyte chemotactic factor, interleukin-8 (IL-8) $(2,3)$. The induction of IL-8 messenger RNA (mRNA) and bioactivity in all three hepatoma lines was found to be stimulus-specific and dose specific - that is, reliant on host-generated signals such as tumor necrosis factor (TNF)- $\alpha$ or IL-1 $\beta$ (but not IL-6). An endogenous (non-host-synthesized) stimulus such as lipopolysaccharide (LPS) does not seem to directly induce hepatoma cells to express IL-8.

Data presented in this report confirm our initial speculation that primary human hepatocytes have the potential to synthesize IL-8. We demonstrate here that cultures of primary human hepatocytes also exhibit a time- and stimulus-specific increase in IL- 8 mRNA and protein in response to doses of TNF- $\alpha$ and IL- $1 \beta$ shown to induce IL-8 in hepatoma cells over the same time period. These findings suggested to us that the most important factor in determining a cell type's ability to express IL-8 initially may not be the level of functional and biochemical complexity expressed by the cell type, but rather the nature of the particular signal or cocktail of signals the cells might be exposed to.

Given that the expression of IL-8 in response to TNF and IL-1 is conserved and similar in hepatoma cells and primary hepatocytes, we have used the SK-hep cell line to demonstrate some of the important in vivo signals for 
inducing IL-8, and their potential sources in human liver. We speculated that IL-8 expression in hepatocytes is contingent on cytokine signals generated by another cell population(s) in the hepatic milieu. Kupffer cells (KCs) which are the fixed tissue macrophages in the liver and the largest population of tissue macrophages in the body, are considered likely candidates as a source of such signal molecules because of their anatomical proximity to hepatocytes, their constant exposure to potential activating factors and their capacity to elaborate a number of potent inflammatory mediators, including TNF- $\alpha$, IL-1 $\beta$ and IL-6 (4-6).

The idea that one cell population can have effects on the function of other cells in its vicinity is a well known phenomenon; phagocytic cells and their secretory products can have profound effects on neighboring cells, ranging from target cell lysis (7-9) to less injurious, noncytotoxic modulation of target cell function (10-11). Specifically, during the past several years, great interest has been devoted to the investigation of KC-hepatocyte interactions, primarily focusing on the nonlethal modulation of hepatocyte function by activated KCs (12-18). This nonlethal effect is reflected by the quantitative and qualitative changes observed in hepatocyte secretory and cellular protein synthesis (19). Both TNF and IL-1 have been implicated in the $\mathrm{KC}$-mediated hepatocyte protein synthetic response (20). It is quite probable that the synthetic changes seen in hepatocellular proteins associated with the acute-phase response (21) are in part mediated by IL-1 (22-24). TNF (23-25) and IL-6 (26-29) elaborated by activated KCs.

Recently, several investigators have demonstrated roles for macrophage/monocyte products such as TNF and IL-1 in a variety of hepatic diseases and inflammatory states with associated neutrophilic infiltrates. Colletti et al. (30) reported a positive correlation between circulating TNF and neutrophilic infiltrates seen in the livers and lungs of rats in a hepatic ischemia/reperfusion model. The authors suggest that TNF (probably of $\mathrm{KC}$ origin)-induced hepatocyte-generated chemotactic factors may be important in the PMN recruitment process. Muto et al. (31) found increased levels of TNF and IL-1 in patients with fulminant hepatic failure; in an analogous animal model Shiratori et al. (32) suggested that products of endotoxin-activated macrophages, and subsequently PMNs, might be involved in the pathogenesis of the liver injury. McClain and Cohen (33) and Bird et al. (34) both reported increased levels of TNF in patients with alcoholic hepatitis and suggested a role for this monokine in the pathogenesis of the disease. Finally, Holman and Saba (35) reported that hepatocellular damage seen in cases of postoperative sepsis may be related to the presence of PMN infiltrates in the liver and suggested that this was a consequence of altered hepatocyte function mediated by $\mathrm{KC}$ activation products.

In this investigation, we sought to establish the existence of an often-implied link between macrophage/monocyte activation products and the production of a chemotactic peptide (IL-8) by the hepatic paren- chyma. We performed experiments to determine whether cultures of primary human hepatocytes synthesize IL-8 in response to proinflammatory stimuli such as TNF and IL-1 $\beta$, to determine whether soluble products of endotoxin-activated $\mathrm{KCs}$ and monocytes could induce IL-8 synthesis by hepatoma cells and to identify some of the macrophage factors involved in the IL-8 induction process.

\section{MATERIAL AND METHODS}

Reagents. Human recombinant TNF- $\alpha$, with a specific activity of $20 \mathrm{U} / \mathrm{ng}$, was provided by Genentech (South San Francisco, CA). Human recombinant IL-6 (10 U/ng, Genzyme Corp., Boston, MA), human recombinant IL-1及 (30 U/ng; Upjohn Co., Kalamazoo, MI), and human recombinant IL-8 $(400 \mathrm{ng} / \mathrm{\mu l}$; acquired from Dr. Ivan Lindley of Sandoz, ForschungsInstitut, Vienna, Austria), were diluted as required in RPMI-1640 medium (Whittaker Biomedical Products, Walkersville, MD). Stock LPS (Escherichia coli 0111:B4; Sigma Chemical Co., St. Louis, MO) solution was prepared at a concentration of $200 \mu \mathrm{g} / \mathrm{ml}$ in RPMI-1640. The chemotactic peptide formylmethionylleucyl phenylalanine (FMLP; Sigma Chemical Co.) was used at a concentration of $10^{-7} \mathrm{~mol} / \mathrm{L}$. Anti-IL-8 and anti-TNF polysera were generated by immunization of rabbits with recombinant human TNF- $\alpha$ and IL-8 at multiple intradermal sites with complete Freunds adjuvant. Monoclonal antibody to human IL-1 $13(700 \mu \mathrm{g} / \mathrm{ml})$ was kindly provided by the Upjohn Co. and was used at a concentration of $7 \mu \mathrm{g} / \mathrm{ml}$. One microgram of this antibody was capable of inhibiting $95 \%$ of the IL-1 $\beta$-induced production of IL-2 by 1 A5 murine T cells.

The human hepatoma cell line SK-hep was obtained from the ATCC human tumor cell bank (American Type Culture Collection, Rockville, MD); it is the cell line originally described by Fogh (36). The line originated from a human liver adenocarcinoma. It is epithelioid in structure and is tumorigenic in nude mice (forming large-cell carcinoma consistent with $\mathrm{HCC}$ ).

Isolation of Cells. Human peripheral blood monocytes (PBMs) and PMNs were isolated from peripheral blood by Ficoll-Hypaque density-gradient centrifugation. PBMs from the gradient were washed extensively in RPMI-1640 medium and diluted to $3 \times 10^{6}$ cells $/ \mathrm{ml}$ in warm RPMI $1640 ; 10 \mathrm{ml}$ of cell suspension was seeded onto $100-\mathrm{mm}$ plates. Cells were incubated at $37^{\circ} \mathrm{C}$ for at least $1 \mathrm{hr}$ to allow adherence and were then washed thoroughly with RPMI 1640 to remove nonadherent cells. PMNs were further purified from the gradient by sedimentation through $5 \%$ dextran/0.9\% sterile saline for 45 min at room temperature. Neutrophils were separated from erythrocytes by hypotonic lysis and suspended in HBSS at $2 \times 10^{6} \mathrm{cells} / \mathrm{ml}$ for chemotaxis.

KCs were isolated from histologically normal liver specimens, which had been harvested 12 to $18 \mathrm{hr}$ earlier but were unsuitable for transplantation, using a modified version of the method described by Magilavy et al. (37). A piece of liver tissue about the size of a rat liver was cut into small pieces and incubated with agitation for $1 \mathrm{hr}$ at $37^{\circ} \mathrm{C}$ in $50 \mathrm{ml}$ collagenase buffer (complete RPMI 1640 medium containing 5\% FCS and $0.03 \% \mathrm{wt} / \mathrm{vol}$ collagenase type IV [Sigma Chemical Co.]). The resulting extract was passed through a 40-gauge mesh filter, and the cell suspension obtained was stored on ice for $10 \mathrm{~min}$. All subsequent procedures were carried out on ice or at $4^{\circ} \mathrm{C}$. The supernatant, which contained primarily nonparenchymal cells (NPCs) (as determined by microscopic analysis), was 
layered gently over a metrizamide density gradient $(17.5 \%$ [wt/vol] metrizamide in RPMI 1640 complete medium with 5\% FCS) and centrifuged for $1 \mathrm{hr}$ at 2,500 rpm in a Beckman TJ-6 tabletop centrifuge using a TH-4 swingout rotor (Beckman Instruments Corp., Palo Alto, CA). The purified NPCs, containing mainly $\mathrm{KCs}$ and some endothelial cells, were recovered from the gradient/supernatant interphase and washed several times in RPMI 1640. Total recovery ranged from 0.9 to $2 \times 10^{7} \mathrm{NPCs} / 5 \mathrm{gm}$ liver. Viability of cells was greater than $90 \%$, as determined by trypan blue uptake. Contamination with parenchymal cells was less than $5 \%$, as determined by microscopical analysis of viable cells. The cell suspension was seeded at a concentration of $6 \times 10^{6}$ $\mathrm{NPCs} / 60-\mathrm{mm}$ plate and allowed to adhere to the plastic for further enrichment of the KCs. At various time intervals (up to $2 \mathrm{hr}$ ) after plating, cultures were examined microscopically to determine the number of cells with a "fried-egg" appearance (i.e., a centrally located nucleus surrounded by a rim of cytoplasm) as described by Smedsrod and Pertoft (38) to be the characteristic structure exhibited by newly adhered KCs. After 2 hours, more than $70 \%$ of the cells had a structure similar to that described above. At this point, cells were washed vigorously and cultured overnight (16 to $20 \mathrm{hr}$ ) in RPMI complete medium supplemented with $10 \%$ FCS. Cultures were again washed vigorously with serum-free medium and finally incubated in RPMI complete medium containing $10 \mu \mathrm{g} / \mathrm{ml}$ LPS for 20 to $24 \mathrm{hr}$ to generate conditioned medium.

Human hepatocytes were isolated from thin slices of transplant donor liver using a modified version of the method described by Rijntjes et al. (39). Liver slices ( 2 to $3 \mathrm{~mm}$ thick) were minced in HEPES buffer ( $\mathrm{pH} 7.6$ ) containing $0.05 \%$ (wt/vol) collagenase (Sigma Type 1; Sigma Chemical Co.) and incubated at $37^{\circ} \mathrm{C}$ for $30 \mathrm{~min}$ in an agitating water bath. This was repeated with the collagenase solution at a final concentration of $0.1 \%$, and the mincing procedure was repeated to further dissociate hepatocytes. The cell suspension was filtered through sterile gauze pads to remove remaining particulate matter, and the filtrate was set on ice for $10 \mathrm{~min}$ to facilitate sedimentation of cells. Cells were pelleted at $50 \mathrm{~g}$ and $4^{\circ} \mathrm{C}$ for 5 min in Beckman TJ-6 centrifuge with a TH-4 rotor (Beckman Instruments Corp.). The resulting cell pellet was resuspended in cold $(0.1 \mathrm{~mol} / \mathrm{L})$ HEPES-Tes buffer ( $\mathrm{pH} 7.6)$ containing $2 \%$ BSA (Sigma fraction V; Sigma Chemical Co.) (incubation buffer) and recentrifuged as above. The pellet was then resuspended in Dulbecco's modified Eagle's medium, $1 \mathrm{mmol} / \mathrm{L}$ glutamine, $100 \mathrm{U} / \mathrm{ml}$ penicillin, $100 \mu \mathrm{g} / \mathrm{ml}$ streptomycin and $10 \%$ FCS (hepatocyte culture medium) in an agitating water bath at $37^{\circ} \mathrm{C}$ for $15 \mathrm{~min}$. The cell suspension was finally passed twice through a sterile 100- $\mu \mathrm{m}$ nylon filter (Spectrum Medical Industries, Inc., Los Angeles, CA). The cell yield was approximately $2.5 \times 10^{6}$ cells/gm tissue. Viability before plating was greater than $90 \%$.

Culture Conditions. SK-hep cells were grown to confluence in RPMI 1640 (supplemented with $1 \mathrm{mmol} / \mathrm{L}$ glutamine, 25 $\mathrm{mmol} / \mathrm{L}$ HEPES, $100 \mathrm{U} / \mathrm{ml}$ penicillin and $100 \mu \mathrm{g} / \mathrm{ml}$ streptomycin [complete medium]) plus $10 \%$ FCS on $60-\mathrm{mm}$ plates at $37^{\circ} \mathrm{C}$ in a humidified atmosphere with $5 \% \mathrm{CO}_{2}$. Cells were subsequently maintained for $24 \mathrm{hr}$ in complete medium, in the absence of FCS, before challenge with a specific stimulus.

Primary hepatocytes were seeded onto collagen (Rat tail, Sigma Type VII; Sigma Chemical Co.)-coated 60-mm culture plates (at a density of 1 to $1.5 \times 10^{6}$ cells $/ \mathrm{cm}^{2}$ ) or Labtek slides (Baxter Scientific Products, McGaw Park, IL) (at a concentration of $1.5 \times 10^{4}$ cells/well) and maintained in hepatocyte culture medium supplemented with $50 \mathrm{nmol} / \mathrm{L}$ dexamethasone at $37^{\circ} \mathrm{C}$ for the first $24 \mathrm{hr}$. Hepatocytes were maintained subsequently for $24 \mathrm{hr}$ in the same medium, minus FCS and dexamethasone, before challenge with a specific stimulus. The experiments were performed in serum- and dexamethasone-free medium, since both factors influence IL-8 expression in hepatoma cells (Thornton AJ, Unpublished data, April 1990).

To generate conditioned medium (CM), adherence-purified PBMs or KCs were incubated with LPS $(10 \mu \mathrm{g} / \mathrm{ml})$ for $24 \mathrm{hr}$ in complete medium. At designated times after stimulation, cell supernatants were collected (particulate matter was removed by centrifugation and stored for bioassay) and cells were prepared for isolation of RNA. For IL-8 mRNA decay studies, SK-hep cells were incubated for 2 or $14 \mathrm{hr}$ with TNF (20 $\mathrm{ng} / \mathrm{ml})$, IL-1 $(20 \mathrm{ng} / \mathrm{ml})$ or CM diluted 1:1 in fresh RPMI medium. The cells were then washed vigorously three times with RPMI medium and RNA was isolated at specified times.

Northern-blot Analysis. Total cellular RNA was isolated from hepatoma cells and hepatocytes, as described previously (2). Equivalent amounts of RNA were separated on $1 \%$ agarose $/ 2.2 \mathrm{~mol} / \mathrm{L}$ formaldehyde gels, blotted to nitrocellulose paper and hybridized with an IL-8-specific or human albuminspecific radiolabeled oligonucleotide probe (for primary hepatocytes), at $56^{\circ} \mathrm{C}$ and $60^{\circ} \mathrm{C}$ respectively, for 12 to $16 \mathrm{hr}$. The IL-8 probe is complementary to the sequence-spanning nucleotides 262-291 of the published complementary DNA (cDNA) for monocyte-derived IL-8 (40). The sequence is 5 '-GTT-GGCGCA-GTG-TGG-TCC-ACT-CTC-AAT-CAC-3'. The albumin oligonucleotide probe has the following sequence: $5^{\prime}$-GCAGTG-CAC-ATC-ACA-TCA-ACC-TCT-GGT-CTC-3'; it is complementary to the nucleotides coding for amino acids 139-149 for the human albumin cDNA sequence present in the National Institutes of Health gene bank (LOO 132 J00078). Blots were washed and exposed to $x$-ray film, with intensifying screens, at $-70^{\circ} \mathrm{C}$ for an appropriate period of time.

Immunohistochemistry. Immunostaining for antigenic IL-8 was performed by fixing SK-hep monolayers or primary hepatocytes on Labtek slides in $4 \%$ paraformaldehyde (in $1 \times$ PBS) for $10 \mathrm{~min}$, followed by three washes with $1 \times$ PBS. Before staining, the slides were treated for $15 \mathrm{~min}$ at room temperature with $1: 13 \% \mathrm{H}_{2} \mathrm{O}_{2} /$ absolute methanol and rinsed in PBS. Nonspecific binding sites were blocked by incubation with a 1:50 dilution of normal goat serum at $37^{\circ} \mathrm{C}(95 \%$ humidified air $/ 5 \% \mathrm{CO}_{2}$ ). After $20 \mathrm{~min}$, the goat serum was replaced with either rabbit antihuman IL-8 or control (rabbit preimmune) serum at a dilution of $1: 2,000$. Slides were incubated for $15 \mathrm{~min}$ as described above, followed by three washes with $1 \times$ PBS. Samples were then overlaid with a biotinylated goat anti-rabbit IgG ( $1: 200$; Vector Laboratories, Burlingam, CA), incubated for $20 \mathrm{~min}$ at $37^{\circ} \mathrm{C}$ (95\% humidified air $/ 5 \% \mathrm{CO}_{2}$ ) and washed three times with $1 \times \mathrm{PBS}$. Slides were subsequently treated with streptavidin-peroxidase conjugate $(1: 100)$ for $15 \mathrm{~min}$ at $37^{\circ} \mathrm{C}$ (as described above) and then washed three times with $1 \times$ PBS. The substrate chromogen (3-amino, 9-ethylcarbazole $[40 \mathrm{mg} / \mathrm{ml}$ in dimethylformamide] $-50 \mu \mathrm{l}$ added to $2 \mathrm{ml} 0.1 \mathrm{~mol} / \mathrm{L}$ sodium acetate buffer [pH 5.2] plus $50 \mu \mathrm{l} 0.3 \% \mathrm{H}_{2} \mathrm{O}_{2}$ ) was then added, and slides were incubated at $37^{\circ} \mathrm{C}$ (as above) for 5 to $10 \mathrm{~min}$ to allow color development. After several rinses in distilled water, slides were counterstained with Mayer's hematoxylin, mounted and examined microscopically.

Chemotaxis Assay. Cell supernatants were assessed for chemotactic bioactivity and IL-8-specific activity as described previously (2). In brief, $255 \mu$ l diluted (1:1) supernatant specimen, $10^{-7} \mathrm{~mol} / \mathrm{L}$ FMLP or HBSS alone (preincubated 


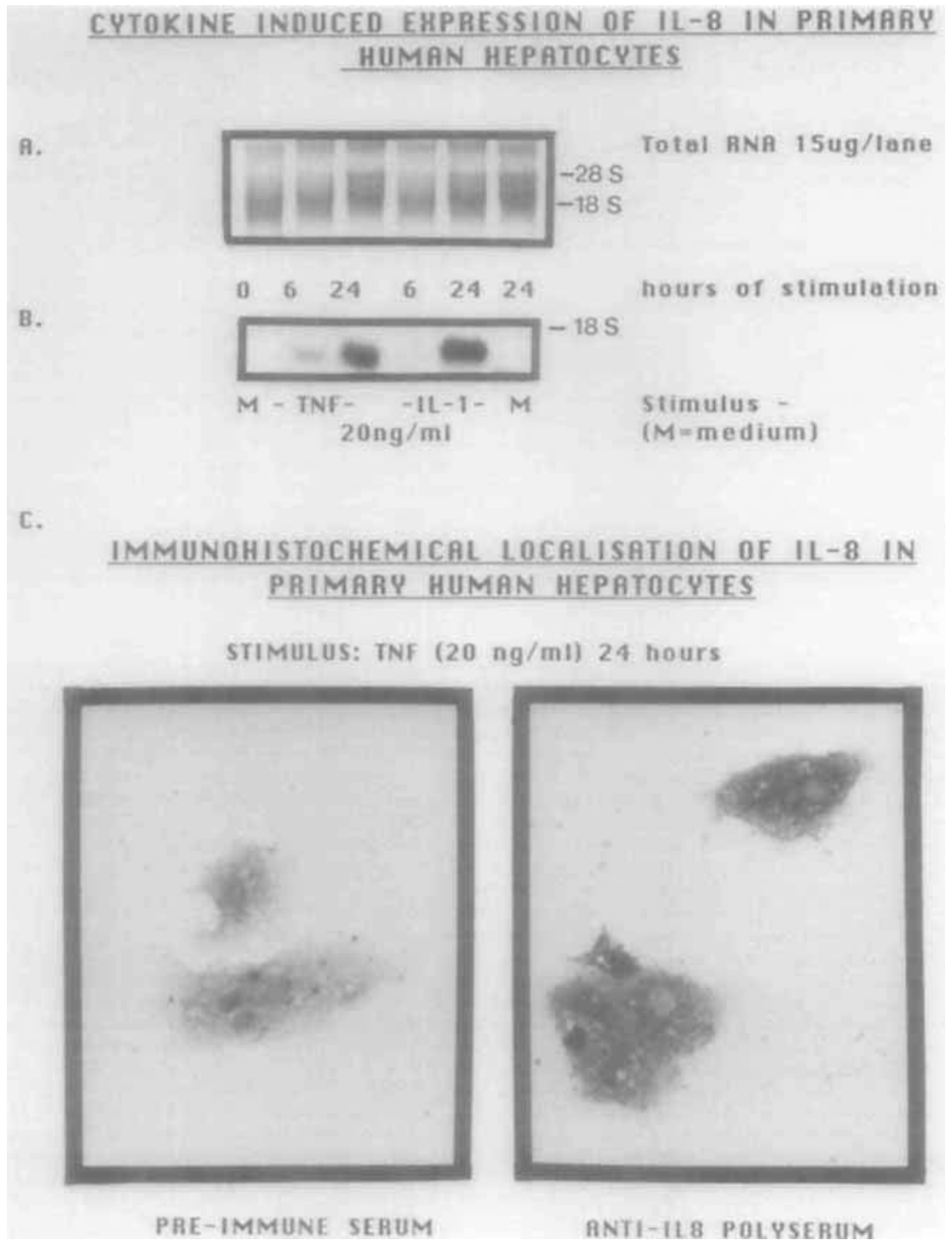

FIG. 1. Cytokine-induced expression of IL-8 mRNA and antigenic protein in cultures of primary human hepatocytes. Cells were stimulated for 0,6 or $24 \mathrm{hr}$ with either TNF or IL-1 $(20 \mathrm{ng} / \mathrm{ml})$ or serum and dexamethasone-free medium $(M)$ without cytokines. Hepatocyte total RNA (panel A) was Northern-blotted and hybridized to an IL-8-specific oligonucleotide probe (panel B) as described in "Material and Methods." (Data are from a single experiment.) Cells were cultured on Lab-tek slides (panel $C$ ) in serum-free medium for $24 \mathrm{hr}$ before a 24-hr stimulation with either TNF or IL-1 $\beta$ (not shown) at $20 \mathrm{ng} / \mathrm{ml}$. Hepatocytes were stained with either rabbit preimmune serum or anti-IL-8 polyserum to determine the presence of cell-associated IL-8 (0-hr samples were negative for IL-8 [not shown]). (Data are representative of two experiments.)

with a $1: 100$ dilution of control [rabbit preimmune] or antihuman IL-8 antiserum for $30 \mathrm{~min}$ at $37^{\circ} \mathrm{C}$ ) was placed in duplicate bottom wells of a blind-well chemotaxis chamber. Three-micron-pore polycarbonate filters (polyvinylpyrrolidone-free; Nucleopore Corp., Pleasanton, CA) were placed in the assembly, and $330 \mu$ neutrophil suspension was placed in each of the top wells. The chemotaxis chambers were incubated at $37^{\circ} \mathrm{C}$ in humidified $95 \%$ air and $5 \% \mathrm{CO}_{2}$ for $1 \mathrm{hr}$. The filters were removed, fixed in methanol and stained with $2 \%$ toluidine blue (Sigma Chemical Co.). Neutrophils that had migrated to the bottoms of the filters were counted in 20 high-power fields (magnification $\times 1,000$ ), and the chemotactic activity was expressed as the mean number of cells per high-power field.

\section{RESULTS}

TNF and IL-1 $\beta$ Induction of IL-8 in Primary Cultures of Human Hepatocytes. The hepatocytes used in these experiments were maintained for only a short period of time ( $72 \mathrm{hr}$ ) in culture (including the time course of the experiments). Although fibroblastlike cells were evident in some cultures, no significant outgrowth of this cell population during the short term culture period we used here was seen.

After $24 \mathrm{hr}$ of culture on collagen-coated plates, the cells had formed an almost confluent monolayer and appeared to have a polygonal structure with granular cytoplasm. The cultures were also synthesizing de- 
(1.)

A.

B.
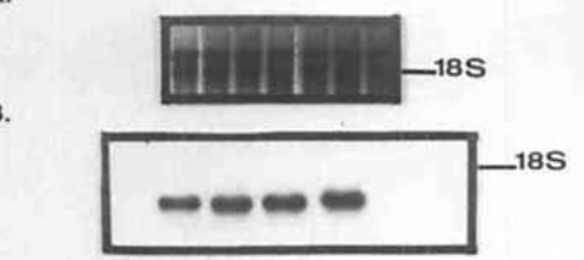

C.

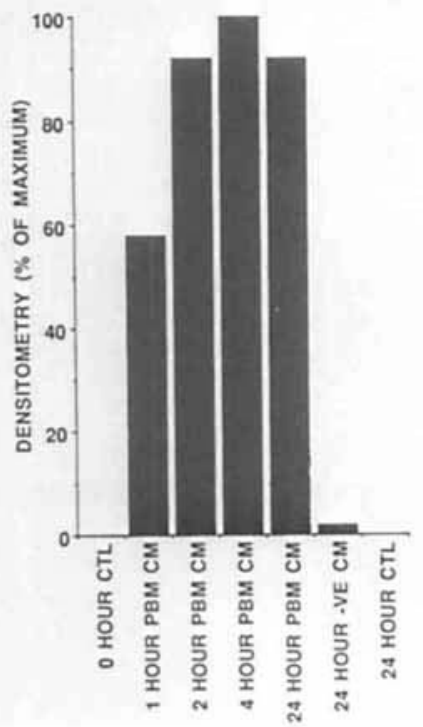

(11)
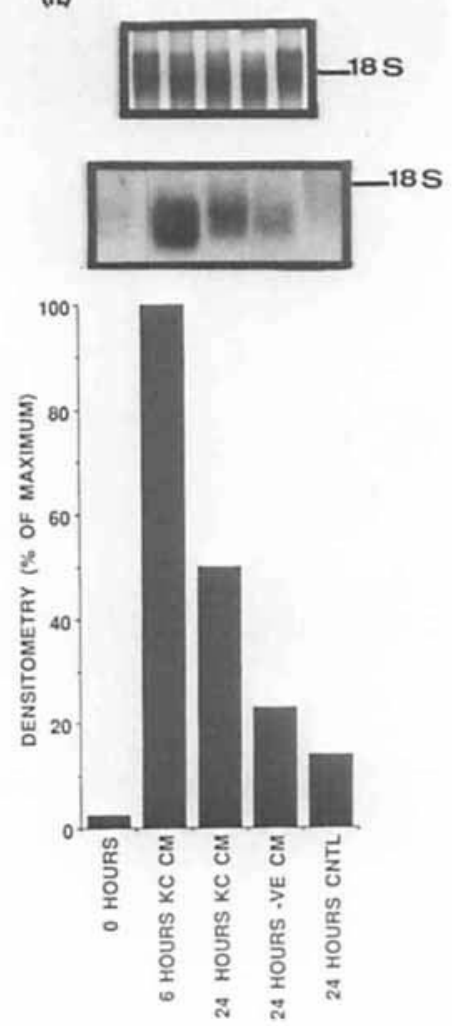

Fig. 2. IL-8 mRNA expression in SK-hep cells exposed to 24-hr CM generated from 24-hr LPS (10 $\mu$ g/ml) stimulated PBM (I) and KCs (II). Cells were stimulated for 0 to $24 \mathrm{hr}$ with either PBM CM or KC CM. (A) Template gels used for Northern blots shown in (B). The relative intensities of autoradiographical signals were quantified by laser densitometry and expressed as a percentage of the maximal value (C). CM generated from unstimulated PBM or KC is designated -ve CM; CTL represents control medium-stimulated cells. The figure is representative of two studies.

tectable levels of albumin mRNA at this point (data not shown). Therefore the cell population used for cytokine induction experiments expressed structural and functional characteristics associated with normal primary hepatocyte cultures.

As demonstrated in Figure 1, human hepatocytes express the gene and synthesize protein for IL-8 on stimulation with TNF and IL-1 $\beta$. The induction appears to be somewhat slower than that seen in hepatoma cells (2), with detectable mRNA levels first evident at about $6 \mathrm{hr}$. However, consistent with hepatoma cell data, significant amounts of mRNA and protein (Fig. 1B and 1C) were present at $24 \mathrm{hr}$. In cell cultures maintained in medium alone, neither IL-8 mRNA (Fig. 1B) nor protein (not shown) was detected at either the 0-hr or 24-hr time points. The effect of LPS on hepatocyte IL-8 expression was not tested in these experiments.

Induction of IL-8 Gene Expression in SK-hep Cells by LPS-stimulated Human PBM and KC CM. To determine whether human PBMs and liver macrophages (KCs) could secrete a soluble factor(s) that would induce IL-8 expression in human hepatoma cells, cell-free CM (24-hr LPS-stimulated, or unstimulated) from PBMs and KCs was incubated with SK-hep monolayers for varying times. As shown in Figure 2, control medium alone did not induce an increase in the IL-8 steady-state mRNA level over $24 \mathrm{hr}$, whereas both LPS-stimulated PBM and KC CM elicited a substantial increase in IL-8 mRNA levels over the same period. For PBM LPS CM, the induction was rapid, with $50 \%$ of the maximal measured IL-8 mRNA level attained within the first hour after stimulation (Fig. 2,IC). A similar data point was not obtained for the KC LPS CM; however, the increase in the IL-8 mRNA level observed $6 \mathrm{hr}$ after stimulation also suggests a rapid induction response (Fig. 2, IIC). A small increase in IL-8 mRNA levels was also observed in SK-hep cells incubated with unstimulated KC CM but not with unstimulated PBM CM.

$I L-8$ mRNA Expression in LPS, IL-6 and TNF-treated SK-hep Cells. Confluent SK-hep monolayers were stimulated with $20 \mathrm{ng} / \mathrm{ml}$ TNF, $10 \mathrm{ng} / \mathrm{ml} \mathrm{IL-6} \mathrm{or} 10 \mu \mathrm{g} / \mathrm{ml}$ LPS and assessed for time-dependent expression of IL-8 mRNA. As shown in Figure 3, only TNF induced a significant increase in the steady-state expression level of IL-8 mRNA in SK-hep cells over $24 \mathrm{hr}$. A similar response was elicited by IL-1 $\beta / \alpha$ (data not shown). Full kinetic data for IL-1 $\beta$ and TNF-induced IL-8 mRNA expression in SK-hep cells was reported recently (2). Neither LPS nor IL-6 induced SK-hep cells to express IL-8 mRNA over the $24-\mathrm{hr}$ period investigated. 
TABLE 1. Immunohistochemical staining of SK-hep cells for IL-8

\begin{tabular}{lccc}
\hline \multicolumn{1}{c}{$\begin{array}{c}\text { SK-hep } \\
\text { stimulus }\end{array}$} & $\begin{array}{c}\text { Mean No. } \\
\text { cells/X400 } \\
\text { field }\end{array}$ & $\begin{array}{c}\text { Mean No. } \\
\text { positively } \\
\text { staining } \\
\text { cells }\end{array}$ & $\begin{array}{c}\text { Percentage } \\
\text { of positively } \\
\text { staining } \\
\text { cells }\end{array}$ \\
\hline PBM LPS CM & 56 & $48 \pm 5.6^{a}$ & 86 \\
KC LPS CM & 67 & $63 \pm 9.7$ & 94 \\
KC-negative CM & 81 & $11 \pm 3.4$ & 14 \\
LPS (10 $\mu$ g/mI) & 63 & $2 \pm 0.8$ & 3 \\
Control medium & 84 & $2 \pm 0.7$ & 2 \\
KC LPS CM & & 0 & 0 \\
\hline
\end{tabular}

SK-hep cells were stimulated for $24 \mathrm{hr}$ with either PBM or KC CM, $\mathrm{KC}$ unstimulated $\mathrm{CM}$ (negative $\mathrm{CM}$ ) or $\mathrm{CM}$ and immunostained with anti-IL-8 polyserum (1:500) or control serum $(1: 500)$. Each manipulation was performed on duplicate slides, and a total of $10 \times 400$ fields counted per duplicate set. Data are expressed as the percentage of IL-8-positive staining cells based on means ( $n=10$ ) determined for the total number of cells and the number of positively staining cells per $\times 400$ field.

${ }^{a}$ S.E.M. $(\mathbf{n}=10)$

${ }^{b}$ Cells were stained with control (rabbit preimmune serum)

Expression of Cell-associated IL-8 Antigen and Chemotactic Bioactivity in SK-hep Cells Exposed to KC and $\boldsymbol{P B M}$ CM. Immunohistochemical analysis was performed on SK-hep cells to confirm the presence of cell-associated IL-8 protein. Cells were cultured in Labtek chambers $(25,000$ cells/well $)$ and incubated with KC CM, PBM CM, LPS or control medium. At specific time intervals (i.e., 4, 8, and $24 \mathrm{hr}$ ), the cells were fixed and immunostained with IL-8-specific antiserum or rabbit preimmune serum. Maximal IL-8 reactivity in SK-hep cells occurred at $24 \mathrm{hr}$ with both PBM and KC LPS-conditioned medium. Eighty-six percent and $94 \%$ of the cells, respectively, demonstrated intense staining for IL-8 (Table 1). Immunoreactive IL-8 was not detected in unstimulated (control) or LPS-stimulated SK-hep cells. However, consistent with the mRNA data, unstimulated KC CM induced a noticeable increase in the number of IL-8-staining cells over control samples, with about $14 \%$ of SK-hep cells expressing antigenic IL-8, compared with $2 \%$ for 24 -hr control medium or $3 \%$ for LPS-stimulated cells (Table 1). In all cases, stimulated SK-hep cells incubated with control serum did not demonstrate immunoreactive IL-8 staining. A representative photomicrograph of IL-8 immunolocalization in SK-hep cells at $24 \mathrm{hr}$ is shown in Figure 4 . Unstimulated KC CM induced a small degree of low-intensity IL-8 staining in the cytoplasm (Fig. 4A); this was far less intense than that seen in LPS-stimulated $\mathrm{KC} \mathrm{CM}-$ treated cells (Fig. 4C). LPS alone did not induce immunoreactive IL-8 (Fig. 4D). The absence of IL-8 staining in control serum-"stained" SK-hep cells is shown in Figure 4B. When PBM CM was used to stimulate the cells, similar results were obtained (data not shown).

To confirm the presence of secreted chemotactic bioactivity in supernatants from CM-treated SK-hep

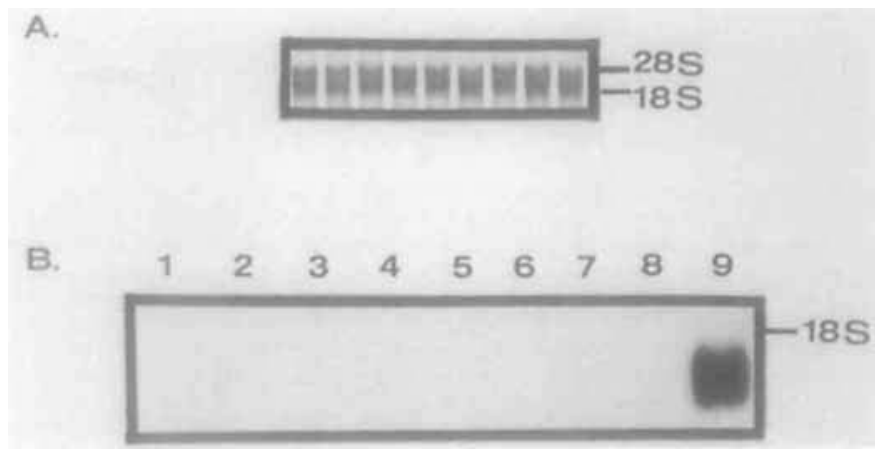

FIG. 3. IL-8 mRNA expression in SK-hep cells exposed to LPS, IL-6 or TNF. (A) Template gel used for Northern blot shown in panel B lane 1, 0-hr control; lane 2, 24-hr control; lanes 3 to 5 , IL-6 (10 ng/ml) for 4,8 and $24 \mathrm{hr}$; lanes 6 to 8 , LPS $(10 \mu \mathrm{g} / \mathrm{ml})$ for 4,8 and $24 \mathrm{hr}$; and lane 9 , TNF (20 $\mathrm{ng} / \mathrm{ml})$ for $24 \mathrm{hr}$. The figure is representative of three studies

cells and to determine the relative contribution of IL-8 to this activity, 24-hr CM was harvested from LPSstimulated KC CM-treated SK-hep cells and tested in a neutrophil chemotaxis assay. As shown in Figure 5, LPS-stimulated, KC CM-treated SK-hep cells produced significant chemotactic activity over the $24-\mathrm{hr}$ period measured. The supernatants of cells treated with LPS alone, control medium or unstimulated $\mathrm{KC} \mathrm{CM}$ also contained chemotactic activity, but at a reduced level $(24 \%, 20 \%$ and $34 \%$, respectively, compared with the LPS-stimulated KC CM-induced activity [100\%]). Preincubation of LPS KC CM-stimulated SK-hep cell supernatants with rabbit antihuman IL-8 polyserum $(1: 500)$ resulted in a reduction of more than $60 \%$ in the chemotactic capacity of the sample (i.e., a mean of 17 cells/high-power field compared with 43 cells/highpower field for control serum-treated samples; Fig. 5). Of note was that IL-8 antibody also blocked a significant proportion $(40 \%)$ of the chemotactic activity generated by unstimulated KC CM-treated SK-hep cells, but had no effect on LPS or control medium-stimulated cells or on the chemotactic capacity of FMLP (data not shown).

Antibodies to TNF-aand IL-1 $\beta$ Reduce IL-8 Expression in KC CM-stimulated SK-hep Cells. Previous work in our laboratory has demonstrated that TNF and IL-1 are potent inducers of IL-8 gene expression in human hepatoma cells (2). In addition, both TNF and IL-1 are known to be major products of activated monocytes and Kupffer cells. To determine whether macrophagederived TNF and IL-1 could be the mediators of KC CM induction of SK-hep IL-8 expression, TNF- and IL-1specific neutralization studies were performed on $24-\mathrm{hr}$ KC CM before incubation with SK-hep monolayers. As shown in Figure 6, preincubation with rabbit antihuman TNF- $\alpha$ polyserum $(1: 100)$ or a murine antihuman IL-1 $\beta$ monoclonal antibody $(7 \mu \mathrm{g} / \mathrm{ml})$ effectively reduced the IL-8-inducing capacity of LPS-stimulated KC CM to about $20 \%$ and $30 \%$, respectively, of nonneutralized 


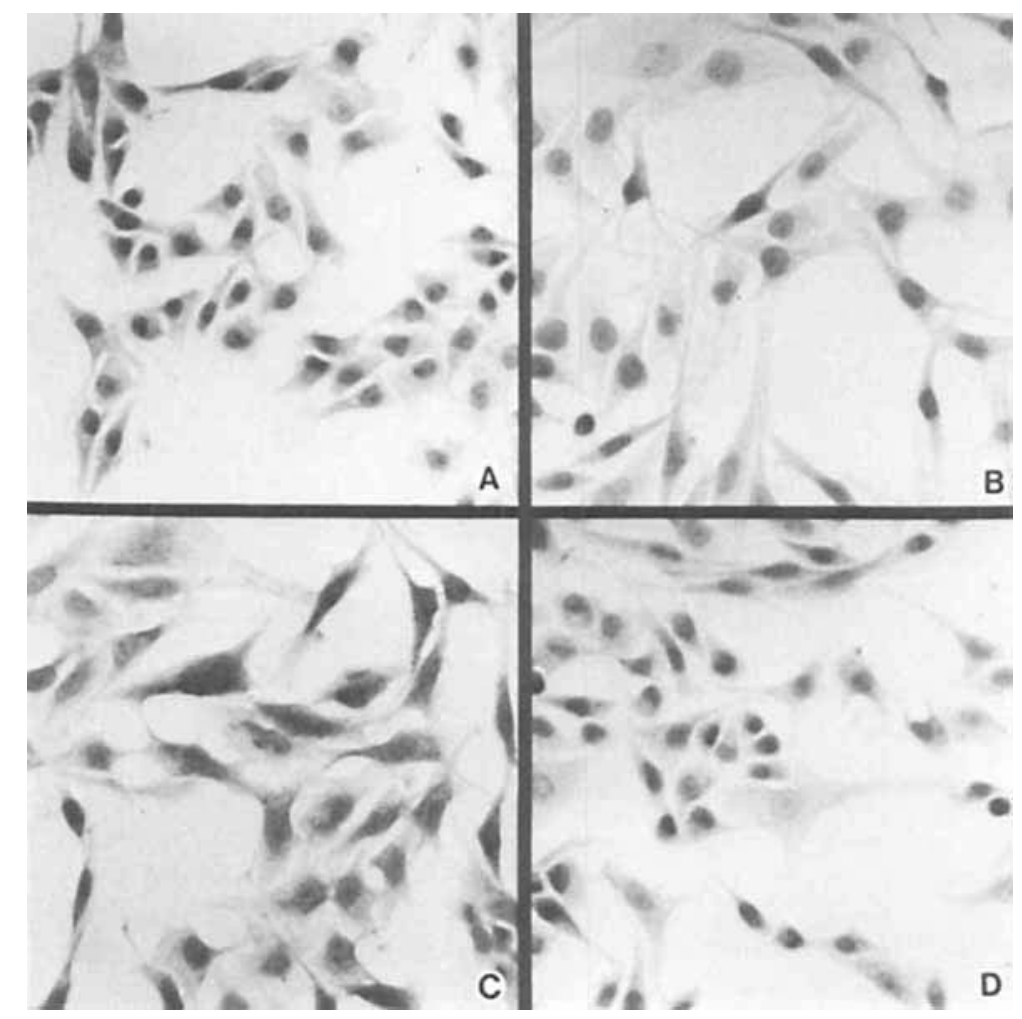

FIG. 4. Expression of immunoreactive IL-8 by stimulated SK-hep cells. Representative photomicrograph of SK-hep cells stimulated for 24 $\mathrm{hr}$ with either LPS-stimulated KC CM, unstimulated (negative) KC CM, control medium (CTL), or LPS alone (10 $\mu \mathrm{g} / \mathrm{ml})$ and immunostained with antihuman IL-8 polyserum or control serum. Panel A shows negative KC CM-stimulated cells stained for IL-8; panels C and B represent cells stimulated with KC CM and stained for IL-8 or with control serum, respectively. Panel D shows SK-hep cells treated with LPS and also stained for IL-8. The figure is representative of multiple experiments.

samples (i.e., samples exposed to control serum only). Incubation of SK-hep monolayers with either unstimulated KC CM, control medium, rabbit preimmune serum or murine IgG resulted in only very low-level expression of IL-8 mRNA at $24 \mathrm{hr}$.

IL-8 mRNA Half-life and Decay Kinetics in SK-hep Cells. To determine whether the IL-8 mRNA half-life and decay kinetics were the same for all three stimuli, we pulsed SK-hep monolayers for $2 \mathrm{hr}$ or $14 \mathrm{hr}$ with TNF, IL-1 $\beta$ or LPS-stimulated CM, and then removed the stimulus. As shown in Figure 7 (B and C), all three stimuli induced significant increases in IL-8 mRNA expression by $2 \mathrm{hr}$ ( 0 hour on graph), with message levels continuing to rise for 15 to $30 \mathrm{~min}$ after stimulation removal. However, once maximal levels were attained, IL-8 mRNA decayed at a rapid rate, falling to $50 \%$ of the maximal level (for all stimuli) within $1 \mathrm{hr}$, declining to undetectable levels between 3 and $6 \mathrm{hr}$ after stimulus removal (the same was true for the 14-hr pulse, data not shown). These data suggest that TNF, IL-1 and PBM CM-induced hepatocyte IL-8 mRNAs have very similar decay patterns and cytoplasmic half-lives of between 40 and $60 \mathrm{~min}$. The same decay pattern and half-life is also observed when cells are pulsed with TNF or IL-1, followed by transcriptional blocking with actinomycin-D (data not shown).

\section{DISCUSSION}

$\mathrm{KCs}$ are an important component of the reticuloendothelial system in the liver (41), and were thought to be mainly involved in the clearance of potentially noxious substances (e.g., LPS) in the sinusoidal circulation. It is now known, however, that KCs elaborate mediators-including lysosomal enzymes, reactive oxygen metabolites, prostaglandins and cytokines - in response to a stimulus such as LPS, which can have profound effects on the functions of the surrounding hepatic parenchyma. Hepatocytes have traditionally been thought of as immunologically inert ("bystander") cells that did not actively contribute to inflammatory/disease processes in the liver. These cells were thought of as target cells rather than effector cells; their functional modulation was considered consequential rather than a contributing factor to the pathogenesis of hepatic disease/inflammatory states. In this study, we present data to reinforce the concept that hepatocytes possess the capacity to function as effector cells in the pathogenesis and perpetuation of inflammatory/disease states in the liver. In addition, we show that KC (and PBM)-derived cytokines TNF and IL-1 may be important mediators of this function, possibly acting as paracrine signals for the induction of hepatocellular IL-8 expression. 


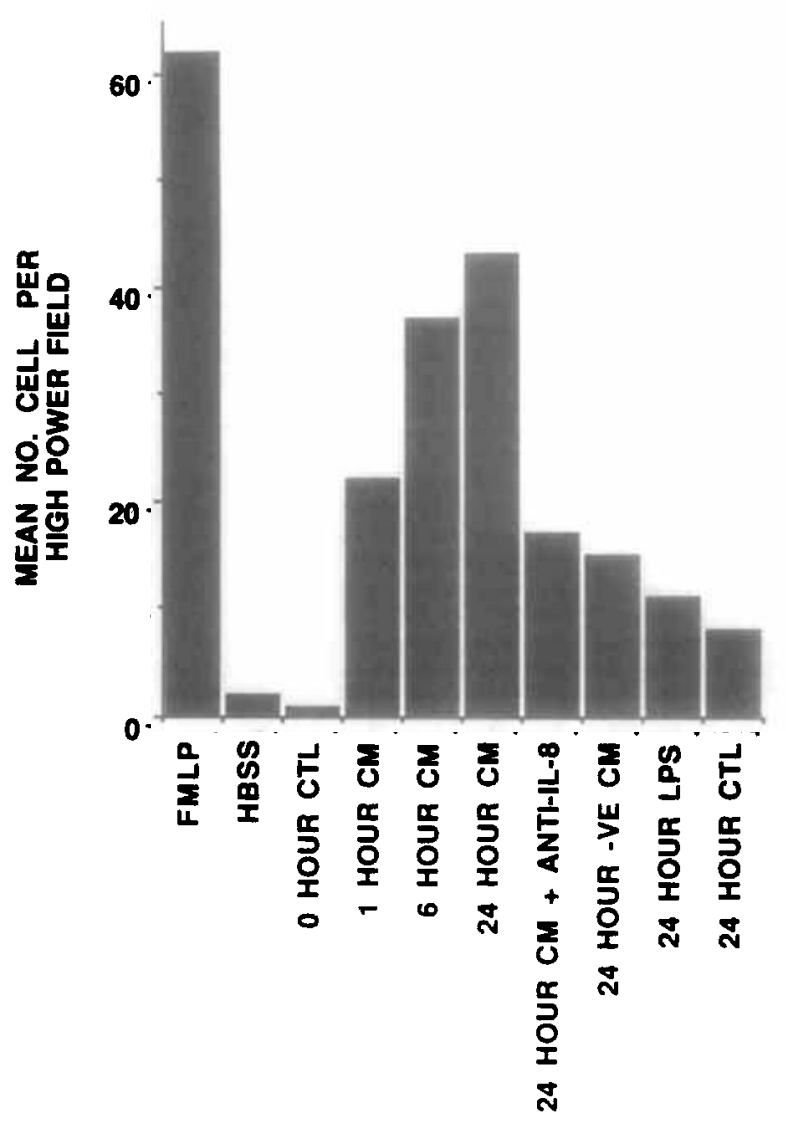

FIG. 5. Secretion of neutrophil chemotactic activity and bioactive IL-8 by KC CM-stimulated SK-hep cells. Cell-free supernatants from SK-hep cells that had been stimulated for various times with $24 \mathrm{hr}$ LPS-stimulated KC CM (CM), $24 \mathrm{hr}$ unstimulated KC CM (-ve CM), LPS $(10 \mu \mathrm{g} / \mathrm{ml})$ or control medium were incubated for $30 \mathrm{~min}$ at $37^{\circ} \mathrm{C}$ with either a $1: 100$ dilution of rabbit antihuman IL-8 (anti-IL-8) or rabbit preimmune (control serum) and assayed for neutrophil chemotactic activity. A total of 20 high-power fields $(\times 1,000)$ were counted per sample, and the chemotactic activity was expressed as the mean number of cells migrating per high-power field. FMLP $\left(10^{\circ}\right.$ $\mathrm{mol} / \mathrm{L}$ ) and HBSS are positive and background controls, respectively, for the assay. Incubation with rabbit control or anti-IL-8 serum had no effect on the chemotactic capacity of these substances (not shown). These data are representative of two separate studies.

We demonstrate that primary human hepatocytes, similar to their hepatoma cell counterparts, have the capacity to synthesize IL-8 in response to cytokines known to be secreted by activated Kupffer cells. Therefore, for the purpose of this discussion, the term "hepatocyte" will be interchanged with SK-hep in referring to IL-8 expression. In addition, we show that LPS-activated KC (and PBM)-conditioned medium induces hepatocyte IL- 8 expression at the levels of mRNA, protein and biological activity. The specific antibodyneutralization studies strongly suggest that $\mathrm{KC}$ derived TNF and IL-1 have major roles in this induction. The inability of IL-6 to induce hepatocyte IL-8 suggests that some degree of stimulus specificity exists in this system, whereas the observation that LPS has no direct effect on hepatocellular IL-8 expression reinforces the concept that host-generated secondary signals are important.

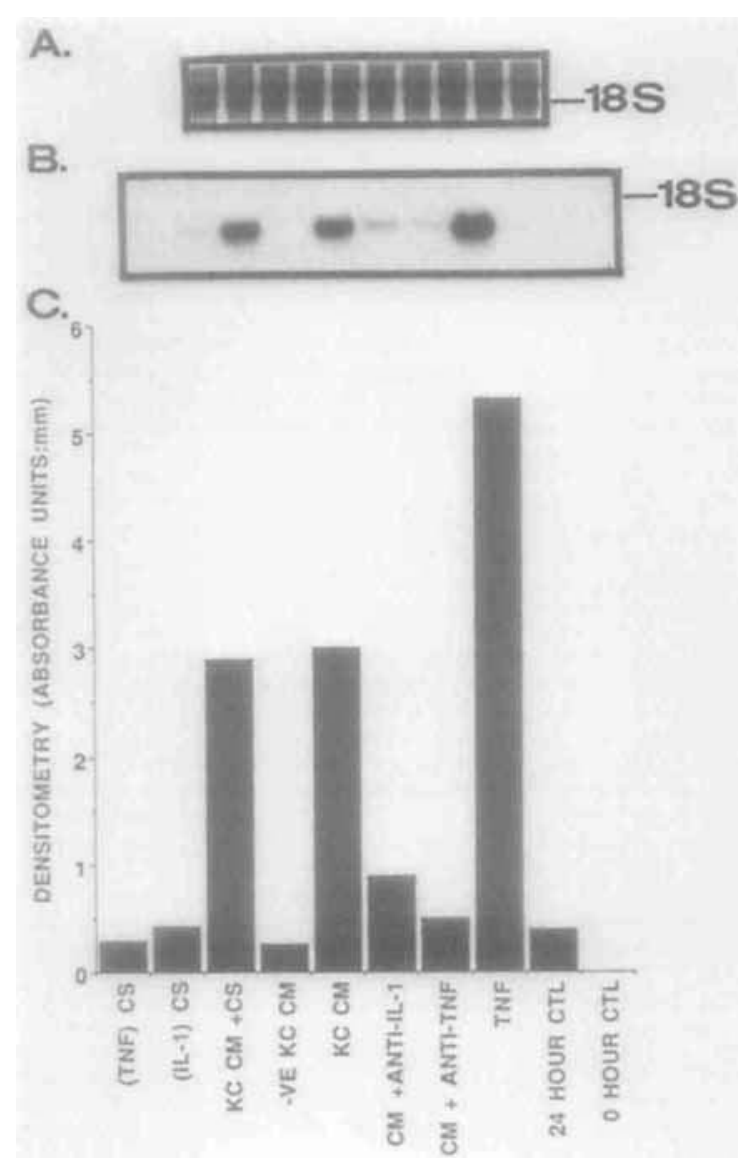

FIG. 6. KC CM-induced IL-8 gene expression in SK-hep cells in the presence and absence of TNF or IL-1 $\beta$ neutralizing antibody. SK-hep cells were exposed for $24 \mathrm{hr}$ to 24 -hr LPS-stimulated KC CM (KC CM), $\mathrm{KC} \mathrm{CM}$ that had been preincubated with anti-TNF (CM + anti-TNF) or anti-IL-1 $(C M+$ anti-IL-1) antibodies or control serum $(K C$ $C M+C S)$ to $C S$ alone (TNF/IL-1 CS) unstimulated KC CM medium (-ve $K C \mathrm{CM})$ or TNF ( $20 \mathrm{ng} / \mathrm{ml})$. IL- $8 \mathrm{mRNA}$ levels were determined by Northern-blot analysis (panels $A$ and $B$ ) and densitometric quantification of autoradiographic signals (panel $C$ ). These data are representative of two individual studies.

$\mathrm{CM}$ from unstimulated $\mathrm{KCs}$ (but not PBM) induced a small but measurable degree of hepatocyte IL-8 mRNA expression and biological activity. This is probably a consequence of $\mathrm{KC}$ activation and cytokine expression during the isolation procedure (i.e., the cells were activated during the liver harvest and subsequent manipulations, the collagenase solution was contaminated with LPS, or both) (PBMs were isolated using endotoxin-free reagents). In fact, we found on analysis that KCs expressed detectable levels of mRNA for TNF and IL-1 (and IL-6) at least $2 \mathrm{hr}$ into culture in the absence of exogenously added LPS (data not shown), supporting our hypothesis that cytokines generated by nonspecifically activated $\mathrm{KCs}$ might account for the observed IL-8 expression in hepatocytes exposed to "unstimulated" CM.

Although we report that a significant proportion of the 


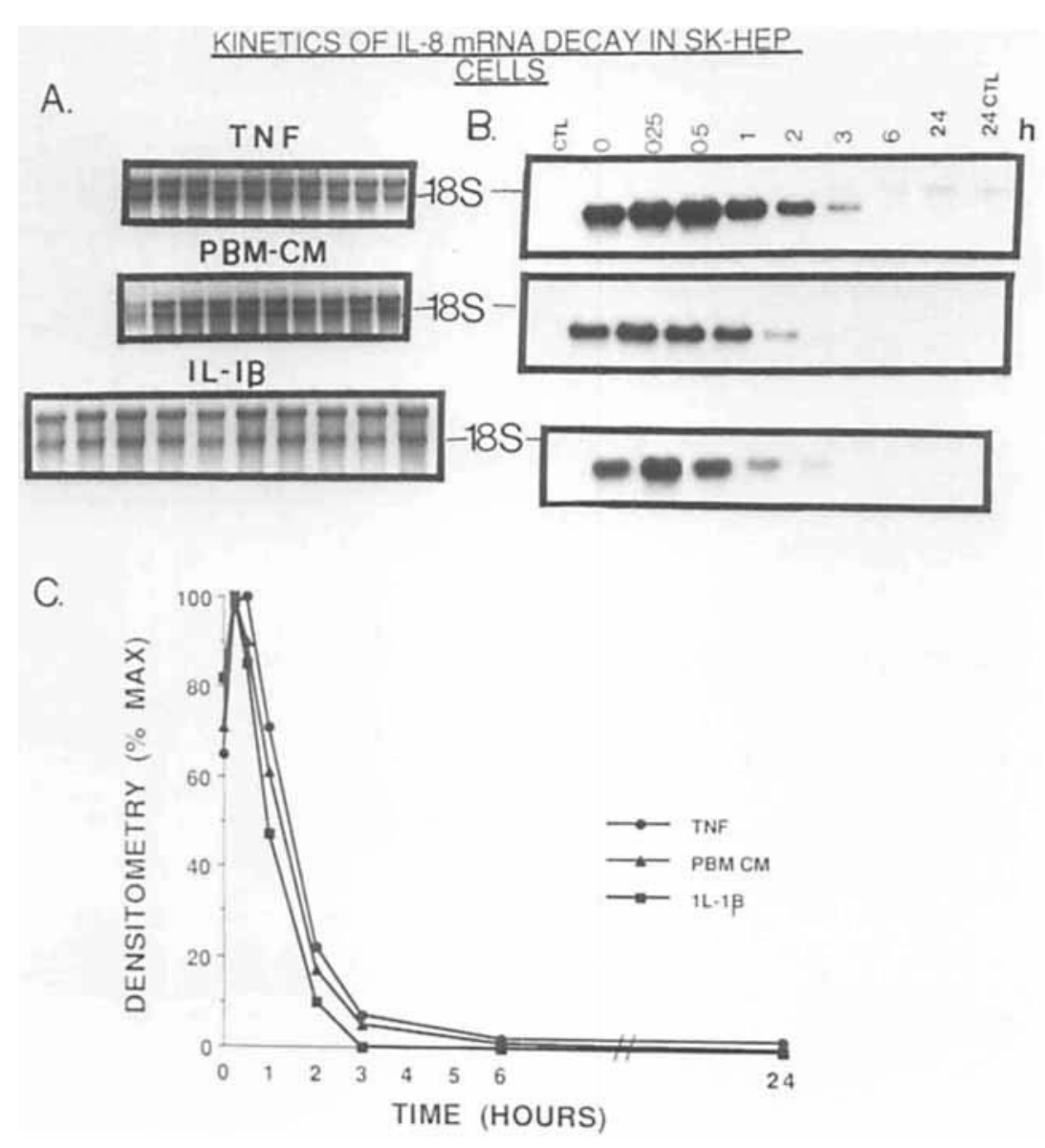

FIG. 7. Kinetics of IL-8 mRNA decay in SK-hep cells that had been pulse-stimulated for $2 \mathrm{hr}$ with TNF (20 ng/ml), IL-1 13 (20 ng/ml) or PBM CM. Panels A and B depict Northern blot analyses of RNAs isolated from SK-hep cells at the indicated times after the removal (0 hr) of the specified stimuli (gels in panel A correspond to adjacent autoradiographs in panel B). CTL and 24 CTL are 2- and 24-hr unstimulated SK-hep cells. The amount of IL-8 mRNA at various times was determined by scanning laser densitometry and is expressed as a percentage of the maximal level attained (C). These data are typical of multiple experiments.

chemotactic activity secreted by hepatocytes is IL-8, it seems likely that some redundancy exists, and hepatocytes may have the ability to produce a small arsenal of chemotactic factors $(42-43)$. We found that these cells can produce chemotactic activity for neutrophils in the absence of IL-8 gene expression when stimulated for 24 $\mathrm{hr}$ with either culture medium or LPS. Although it is possible that this observation was due to a direct effect of LPS on the neutrophils, it seems unlikely, since LPS does not appear to be chemotactic for PMN in vitro (44). However, even though hepatocytes are generally considered unresponsive to LPS, it is possible that these cells release neutrophil chemoattractants other than IL-8 as a direct response to LPS. Mazuski et al. (45), for example, reported the synthesis of a secreted protein of as-yet-unknown function by LPS-treated hepatocytes in culture. Arachidonic acid metabolites, such as leukotriene $B_{4}$, are obvious candidates for possible chemotactic substances secreted by hepatocytes, but Perez et al. (42) and Shiratori et al. (46) have mostly ruled out this possibility. Alternatively, hepatocellular secretion of complement factors (47), some of which can function as chemoattractants for PMN (48), may account for the non-IL-8-specific chemotactic activity that we have observed.

As for the induction kinetics of IL-8 expression, we found that the decay kinetics are also rapid, whether the induction signal is TNF, IL-1 or monocyte/macrophage CM. Several lines of evidence exist to suggest that both transcriptional and pretranslation mechanisms mediate this regulation. Dixit et al. (49) and Matsushima and Oppenheim (50) have reported that TNF and IL-1 induction, respectively, of endothelial cell IL-8 is by a transcriptional mechanism. In this study, we demonstrate that the stimulus-induced increase in IL-8 mRNA levels seen with TNF, IL-1 and CM is probably transcriptional and not due to increased message stability, since no difference exists in IL-8 mRNA half-life at 2 and $14 \mathrm{hr}$ after induction. Although we do not demonstrate it specifically for IL-8 in this report, several investigators have proposed putative posttranscriptional/pretranslational regulatory mechanisms for a variety of cytokines whose mRNAs, like IL-8, have short half-lives. These cytokines include IL-2, IL-1, TNF, GM-CSF and 
interferon- $\gamma$ (51-53). Like IL-8, these cytokines all share a highly conserved AUUUA motif in their $3^{\prime}$ untranslated mRNA regions; this is thought to confer message instability by targeting such mRNAs for rapid cytoplasmic degradation (51-54). Based on these and our own observations, it would appear that the molecular regulation of IL-8 in hepatoma cells and hepatocytes is complex. Evidence suggests that KC and PBM products are integral components of IL-8 regulatory mechanisms, demonstrating the potential importance of cell-cell (cytokine) communication networks (between NPCs and parenchymal cells) in regulating host responses in liver disease and inflammation.

In conclusion, in a number of recent reports (30$35)$, the presence of increased levels of the macrophage/monocyte derived cytokines TNF- $\alpha$ and IL-1 has been correlated to specific liver disease and inflammatory states with associated leukocytic infiltrates. Our data suggest that in such conditions, the action of nonparenchymal cell-derived TNF and/or IL-1 on the liver parenchyma could induce IL-8 expression and, consequently, the influx of specific inflammatory cells. This would account in part for the presence of such infiltrates in some of the liver disease and inflammatory states mentioned above. Furthermore, given that both normal and transformed hepatocytes synthesize IL-8, it is conceivable that the production of this protein contributes not only to the pathologies observed in nonneoplastic liver disease and inflammation, but also those seen in HCCs and other tumors.

Acknowledgments: We thank S. Miller and P. Otto for secretarial assistance and $\mathrm{H}$. Evanoff for tissue culture support.

\section{REFERENCES}

1. Lefkowitch JH. Liver biopsy interpretation short course No. 20. Proceedings of the 78th annual meeting of the United States and Canadian Academy of Pathology. 1989:4-15.

2. Thornton AJ, Strieter RM, Lindley I, Baggiolini M, Kunkel SL. Cytokine-induced gene expression of a neutrophil chemotactic factor/IL-8 in human hepatocytes. J Immunol 1990;144:2609-2613.

3. Baggiolini M, Walz A, Kunkel SL. Neutrophil-activating peptide1/interleukin-8, a novel cytokine that activates neutrophils. J Clin Invest 1989;84:1045-1049.

4. Shirahama M, Ishibashi Y, Tsuchiya S, Kurokawa Y, Okumura Y, Nino $Y$. Kinetics and parameters of the induction of interleukin-1 secretion by rat Kupffer cells. J Clin Lab Immunol 1988;27: 127-132.

5. Karck U, Peters T, Decker K. The release of tumor necrosis factor by endotoxin-stimulated rat Kupffer cells is regulated by prostaglandin E2 and dexamethasone. J Hepatol 1988;7:352-361.

6. Chensue W, Terebuh PD, Remick DG, Scales WE, Kunkel SL. In vivo biologic and immunohistochemical analysis of interleukin-1 $\alpha, \beta$ and tumor necrosis factor during experimental endotoxemia: kinetics. Kupffer cell expression and glucocorticoid effects. Am J Pathol 1991;138:395-402.

7. Nathan CF, Brukner LH, Silverstein SC, Cohn AZ. Extracellular cytolysis by activated macrophages and granulocytes. I. Pharmacologic triggering of effector cells and the release of hydrogen peroxide. J Exp Med 1979;149:84-99.

8. Stukart MJ, Rijnsent A, Roos E. Induction of tumoricidal activity in isolated rat liver macrophages by liposomes containing recombinant rat $\gamma$-interferon supplemented with lipopolysaccharide and muramyldipeptide. Cancer Res 1987;47:3880-3885.
9. Sherwood ER, Williams DL, MeNamee RB, Jones EL, Browder IW, Di Luzio NR. In vitro tumoricidal activity of resting and glucanactivated Kupffer cells. J Leuk Biol 1987;42:69-75.

10. Kawakami M, Pekala PH, Lane MD, Cerami A. Lipoprotein lipase suppression in 3T3-LI cells by an endotoxin-induced mediator from exudate cells. Proc Natl Acad Sci USA 1982;79:912-916.

11. Pekala PH, Kawakami M, Angus CW, Lane MD, Cerami A. Selective inhibition of synthesis of enzymes for de novo fatty acid biosynthesis by an endotoxin-induced mediator from exudate cells. Proc Natl Acad Sci USA 1983;80:2743-2747.

12. Keller GA, West MA, Cerra FB, Simmons RL. Multiple systems organ failure: modulation of hepatocyte protein synthesis by endotoxin activated Kupffer cells. Ann Surg 1985;201:87-95.

13. Keller GA, West MA, Wilkes LA, Cerra FB, Simmons RL. Modulation of hepatocyte protein synthesis by endotoxin activated Kupffer cells. II. Mediation by soluble transferable factors. Ann Surg 1985;201(4):429-435.

14. Keller GA, West MA, Harty JT, Wilkes LA, Cerra FB, Simmons RL. Modulation of hepatocyte protein synthesis by endotoxin activated Kupffer cells. III. Evidence for the role of a monokine similar to but not identical with interleukin-1. Ann Surg 1985; 201:436-443.

15. Keller GA, West MA, Cerra FB, Simmons RL. Macrophagemediated modulation of hepatocyte protein synthesis. Arch Surg 1986;121:1199-1205.

16. West MA, Keller GA, Hyland BJ, Cerra FB, Simmons RL. Hepatocyte function in sepsis: Kupffer cells mediate a biphasic protein synthesis response in hepatocytes after exposure to endotoxin or killed $E$. coli. Surgery 1985;98:388-394.

17. West MA, Keller GA, Hyland BJ, Cerra FB, Simmons RL. Further characterization of Kupffer cell/macrophage-mediated alterations in hepatocyte protein synthesis. Surgery 1986;100:416-422.

18. West MA, Billiar TR, Curran RD, Hyland BJ, Simmons RL. Evidence that rat-Kupffer cells stimulate and inhibit hepatocyte protein synthesis in vitro by different mechanisms. Gastroenterology 1989;96:1572-1582.

19. West MA, Billiar TR, Mazuski JE, Curran RD, Cerra FB, Simmons RL. Endotoxin modulation of hepatocyte secretory and cellular protein synthesis is mediated by Kupffer cells. Arch Surg 1988; $123: 1400-1405$.

20. Cerra FB, Mazuski JE, Baukey PE, Billiar TR, Holman RT. Role of monokines in altering hepatic metabolism in sepsis. In: Roth BL, Nielsen TB, McKee AE, eds. Molecular and cellular mechanisms of septic shock. Prog Clin Biol Res 1989;286:265-277.

21. Koj A. In: Allison AC, ed. Structure and function of plasma protein. Vol. I. New York: Plenum, 1974:73.

22. Ramadori G, Sipe JD, Dinarello CA, Mizel VB, Colten HR. Pretranslational modulation of acute phase hepatic protein synthesis by murine recombinant human Interleukin-1 (IL-1) and purified human IL-1. J Exp Med 1985;162:930-942.

23. Darlington GJ, Wilson DR, Lachman LB. Monocyte conditioned medium, interleukin-1 and tumor necrosis factor stimulate the acute phase response in human hepatoma cells in vitro. J Cell Biol $1986 ; 103: 787-793$.

24. Andus T, Geiger T, Hirano T, Kishimoto T, Heinrich PC. Action of recombinant human interleukin- $1 \beta$ and tumor necrosis factor- $\alpha$ on the mRNA induction of acute phase proteins. Eur J Immunol 1988;18:739-746.

25. Perlmutter DH, Dinarello CA, Punsal PI, Colten HR. Cachectin/tumor necrosis factor regulates hepatic acute phase gene expression. J Clin Invest 1986;78:1349-1354.

26. Ramadori G, Van Damme J, Reider H, Meyer zum Büschenfelde K-H. Interleukin-6, the third mediator of acute phase reaction, modulates hepatic protein synthesis in human mouse: comparison with interleukin-1 $\beta$ and tumor necrosis factor- $\alpha$. Eur J Immunol 1988;18:1259-1264.

27. Baumann H, Onorato V, Gauldie J, Jahreis GP. Distinct sets of acute phase plasma proteins are stimulated by separate human hepatocyte-stimulating factors and monokines in rat hepatoma cells. J Biol Chem 1987;262:9756-9768.

28. Markinovic S, Jahreis GP, Wong GG, Baumann H. IL-6 modulates the synthesis of a specific set of acute phase plasma proteins in vivo. J Immunol 1989;142:808-812. 
29. Gauldie J, Northemann W, Fey GH. IL-6 functions as an exocrine hormone in inflammation: hepatocytes undergoing acute phase responses require exogenous IL-6. J Immunol 1990;144:38043808.

30. Colletti LM, Remick DG, Burtch GD, Kunkel SL, Strieter RM, Campbell DA Jr. Role of tumor necrosis factor- $\alpha$ in the pathophysiologic alterations after hepatic ischemia/reperfusion injury in the rat. J Clin Invest 1990;85:1936-1943.

31. Muto Y, Nouri-Aria KT, Meager A, Alexander GJM, Eddelston ALWF, Williams R. Enhanced tumor necrosis factor and interleukin-1 in fulminant hepatic failure. Lancet 1988;2:72-74.

32. Shiratori Y, Tanaka M, Hai K, Kawase T, Shiina S, Sugimoto T. Role of endotoxin-responsive macrophages in hepatic injury. HEPATOLOGY 1990;11:183-192.

33. MeClain CJ, Cohen DA. Increased tumor necrosis factor production by monocytes in alcoholic hepatitis. HEPATOLOGY 1989;9: 349-351.

34. Bird GLA, Sheron N, Goka AKJ, Alexander GJ, Williams RS. Increased plasma tumor necrosis factor in severe alcoholic hepatitis. Ann Intern Med 1990;112:917-920.

35. Holman JM Jr, Saba TM. Hepatocyte injury during post-operative sepsis: activated neutrophils as potential mediators. J Leukoc Biol 1988;43:193-203.

36. Fogh J, Trempe G. In: Fogh J, ed. Human tumor cells in vitro. New York: Plenum Press, 1975:115-159.

37. Magilavy DB, Hundley TR, Steinberg AD, Finbloom DS. Abnormal binding of soluble IgG immune complexes to hepatic nonparenchymal cells of autoimmune mice. J Immunol 1983;131:27842788.

38. Smedsrod B, Pertoft H. Preparation of pure hepatocytes and reticuloendothelial cells in high yield from a single rat liver by means of percoll centrifugation and selective adherence. $J$ Leukoc Biol 1985;38:213-230.

39. Rijntjes PJM, Moshage HJ, Van Geurest PJL, DeWaal R, Yap SH. Cryopreservation of adult human hepatocytes: the influences of deep freezing storage on the viability, cell seeding, survival, fine structure and albumin synthesis in primary cultures. J Hepatol $1986 ; 3: 7-18$

40. Yoshimura T, Matsushima K, Tauka S, Robinson EA, Appella E, Oppenhiem JJ, Leonard EJ. Purification of a human monocytederived neutrophil chemotactic factor that shares sequence homology with the host defence cytokines. Proc Natl Acad Sci U.S.A. 1987;84:9233-9237.

41. Nolan JP. Endotoxin, reticuloendothelial function and liver injury. HEPATOLOGY 1981;1:458-465.

42. Perez HD, Roll FJ, Bissell DM, Shak S, Goldstein IM. Production of chemotactic activity for polymorphonuclear leukocytes by cultured rat hepatocytes exposed to ethanol. J Clin Invest 1984;74:1350-1357.

43. Shiratori Y, Takada H, Hai K, Matsumoto K, Kamii K, Okano K, Tanaka M. A mechanism of accumulation and activation of neutrophils and monocytes in alcoholic liver injury: roles of chemotactic factors produced by hepatocytes [Abstract]. HEPATOLOGY 1989;10:704.

44. Issekutz A, Bhimji S. Role of endotoxin in the leukocyte infiltration accompanying $E$. coli inflammation. Infect Immun 1982; 36:558-566

45. Mazuski JE, Platt J, West MA, Simmons RL, Towle HC, Cerra FB. Direct effects of endotoxin on hepatocytes: synthesis of a specific secretory protein. Arch Surg 1988;123:340-344.

46. Shiratori Y, Moriwaki H, Muto Y, Onishi H, Kato M, Asano F. Production of leukotrine $B_{4}$ in parenchymal and sinusoidal cells of the liver in rats treated with D-galactosamine and endotoxin. Gastroenterol Jpn 1989;24:640-645.

47. Ramadori G, Rasokat H, Burger R, Meyer zum Büschenfelde $\mathrm{K}-\mathrm{H}$, Bitter-Suermann D. Quantitative determination of complement components produced by purified hepatocytes. Clin Exp Immunol 1984;55:189-196.

48. Fernandez HN, Henson PM, Otani A, Hugli TE. Chemotactic response to human $\mathrm{C} 3 \mathrm{a}$ and $\mathrm{C} 5 \mathrm{a}$ anaphylatoxin. I. Evaluation of C3a and C5a leukotaxis in vitro and stimulated in vivo conditions. $\mathrm{J}$ Immunol 1978;120:109-115.

49. Dixit VM, Green S, Sarma V, Holzman LB, Wolf FM, O'Rourke K, Ward PA, et al. Tumor necrosis factor- $\alpha$ induction of novel gene products in human endothelial cells including a macrophagespecific chemotaxin. J Biol Chem 1990;265:2973-2978.

50. Matsushima K, Oppenheim JJ. Interleukin 8 and MCAF: novel inflammatory cytokines inducible by IL-1 and TNF. Cytokine $1989 ; 1: 2-13$.

51. Shaw G, Kamen R. A conserved AU sequence from the 3 'untranslated region of GM-CSF mRNA mediates selective mRNA degradation. Cell 1986;46:659-667.

52. Caput D, Beutler B, Hartog K, Thayes R, Brown-Shimer S, Cerami A. Identification of a common nucleotide sequence in the 3'-untranslanted region of mRNA molecules specifying inflammatory mediators. Proc Natl Acad Sci USA 1986;83:16701674.

53. Lindsten T, June $\mathrm{CH}$, Ledbetter JA, Stella G, Thompson CB. Regulation of lymphocyte messenger RNA stability by a surfacemediated T cell activation pathway. Science 1989;244:339-343.

54. Malter JS. Identification of an AUUUA-specific messenger RNA binding protein. Science 1990;246:664-666. 